\title{
THE RESEARCH WORK OF FUTURE COMPUTER SCIENCE TEACHERS IN UKRAINE
}

\author{
Yuliia Minhalova \\ Assistant, Zhytomyr Ivan Franko State University, Ukraine \\ e-mail: mingalyovay@gmail.com,orcid.org/0000-0003-1706-2673
}

\section{Summary}

Due to the conducted scientific literature analysis in the article, the main stages (preparatory-target, procedural-substantive, experimental-effective) of the organization of scientific-activity of future teachers of computer science in Ukraine are covered. The need to use information and communication technologies (ICT) in the organization of research work of future teachers of computer science is emphasized. The article defines the concept of "research work of higher education seekers". The analysis of the available information and communication technologies allowed to single out the following types of means for the organization of research work of future teachers of computer science: means of search, storage and placement of scientific materials; ICT tools for collaboration; ICT tools for verification of materials of performed scientific works; means of checking software code for plagiarism; ICT tools to support experimental research; ICT tools to create demonstration material. It is noted that the main characteristics of ICT for the organization of research work: individualization of scientific work; search engine optimization; convenient means for cooperation, etc. The article identifies areas for further research on this topic.

Keywords: research work, students of higher education, future teachers of computer science, information and communication technology, organization of research work of the future teachers of computer science.

DOI https://doi.org/10.23856/3925

\section{Introduction}

The current stage of the world community development places new increasing demands on the level of training of specialists in any field, the use of information and computer technology in professional activities. Ukraine is undergoing significant economic and social reforms, which significantly affect the formation of new requirements for future professionals in the field of education. Appropriate training requirements are undergoing changes, one of which is the requirement to develop a creative and enterprising specialist who will have organizational skills and ability to direct activities (own and / or led group) to improve the process by implementing new advances in science and technology. Fulfillment of this requirement requires wide involvement of applicants for higher education in scientific activities, their direct inclusion in the research work of the institution of higher education.

According to the Law of Ukraine "On Higher Education", scientific activity in higher education institutions (HEI) is an integral part of the educational process and is carried out in order to integrate it into the higher education system and is mandatory for HEI. (Law of Ukraine “On Higher Education”, 2018).

In previous works, the author of the article considered information and communication technologies as one of the means of implementing research activities of students (Minhalova, 2018), principles of using flexible Scrum project management in research work of 
students (Minhalova, 2018), organization of student research activities in classes on the subject "Fundamentals of Scientific Research" (Minhalova, 2018) and use Google to support and support student research (Minhalova, 2019).

\section{Participants and Stages of Organization of Research}

According to the Law of Ukraine "On Higher Education" the main purpose of scientific activity is to acquire new scientific knowledge by conducting research and development and directing them to create and implement new competitive technologies, types of equipment, materials, etc. to ensure innovative development of society, training of innovative specialists. (Law of Ukraine "On Higher Education”, 2018).

The Law of Ukraine "On Higher Education" defines the main tasks of scientific activity of higher education institutions:

1) to obtain competitive scientific and scientific-applied results;

2) to apply new scientific, scientific and technical knowledge during the training of specialists who have already abstained higher education;

3) to form modern scientific personnel potential capable to ensure the development and implementation of innovative scientific developments (Law of Ukraine "On Higher Education”, 2018).

Research work of higher education students is an independent creative activity that requires targeted self-organization for students to learn in the learning process at different stages of the research and innovative cycle, including basic and applied research to solve the problems. Participants in the organization of research work of higher education institutions include:

- representatives of the administration of HEI;

- teaching staff of HEI;

- applicants for higher education.

The analysis of the scientific and pedagogical literature provided an opportunity to identify the following stages of the organization of research work of applicants for higher education:

- the first stage - preparatory-target - is aimed at acquaintance with sequence and interrelation of constituent elements of research work in higher education institutions, encouragement of students of HEI to research work, expansion of their scientific outlook, motivation of students in involvement in scientific activity, creation of favorable conditions of search development, cognitive and research interest of future professionals, the formation of their needs for scientific research and professional development throughout the life;

- the second stage - procedural-substantive involves students mastering the basic methods of research work through individual consultations, lectures; preparation for research work by writing essays, scientific reports; conducting debates, dialogues, interviews; inclusion of students in cognitive research activities in seminars and practical classes; choice of topic (course, bachelor's, master's thesis) and its formulation, comprehension and selection of actual scientific material on the selected problem, compilation of bibliography, analysis of scientific material, experiment (experiment), processing, analysis and generalization of work results, formulation of conclusions, registration of the manuscript of work according to the current requirements; participation in the work of scientific circles, problem groups, other forms of research work of higher education seekers;

- the third stage - experimental-effective - is to gain experience in writing the text of the report and illustrative material, preparation and adjustment of models, models, devices, etc. to demonstrate their own scientific work in the form of public speaking, testing results at 
conferences, forums, symposia; participation in competitions, contests, grants; participation in educational, production or research projects.

\section{Information and Communication Technologies (ICT) in the Organization of Research Work of Future Teachers of Computer Science}

The professional training of future computer science teachers should be implemented as a comprehensive pedagogical process that takes into account the use of ICT for higher education and improving its quality, as a decisive factor in shaping the level of readiness of specialists to solve professional and scientific problems. (Kharkivska, 2012).

Scientists note that the use of specialized educational software resources provide the opportunity to: computer visualization of the necessary material; remote feedback between participants of scientific work; storage and transmission of large amounts of data; quick access of higher education applicants to abstract data banks; automate the processes of information retrieval activities; to process the results of the educational experiment with the possibility of reproducing it in whole or in part (Vinnyk, Osypova, Tarasich, Savenko, 2014).

The analysis, which was given above indicates the urgency of solving the problem of deepening the links between education, science and industry, namely: the expanding cooperation between educational and research institutions; the improving the ways of interaction between the corporate customer and higher education institutions; the deepening of the relationship between science and society by participating in solving problems of social and economic nature: improving the process of training and organization of scientific research.

The analysis of the available information and communication technologies which it is expedient to use at the organization of research work of the future teachers of computer science has allowed to allocate such types of means:

A. Means of search, storage and placement of scientific materials - Means of search, storage and placement of scientific materials system of search of scientific resources and materials in electronic networks; services for placing materials of various formats in free access on the Internet and those that serve to preserve the necessary for the research work of the future teacher of computer science electronic pages, etc.:

- search engines (for example, Google, Yandex, Bing);

- institutional repositories and electronic libraries (for example, arXiv.org, Google Scholar, Research Gate, Sci-Hub, Social Science Research Network, Digital Bibliography \& Library Project, Public Library of Science, Scopus);

- social bookmarks (for example, Delicious, Bibsonomy, Zeto);

- multimedia information dissemination systems (for example, YouTube, iTunes, Scribd, Flicker, SlideShare).

B. ICT tools for collaboration - systems of cooperation of young researchers for editing and content creation, organization of joint work of applicants for higher education and research supervisors, with the help of which future computer science teachers can perform group projects and abstracts, prepare joint reports, work with the teacher on term papers and dissertations, communication tools subjects of research work by means of e-mail, videoconferences, discussions, chat, announcements, online repositories of materials of research work by means of which teachers and future teachers of computer science download files with the corresponding content of various format (text, graphic, audio, video, etc.), services to provide the possibility of joint simultaneous access to documents of different formats and work with them, etc., which take place on the Internet, online lectures, distance learning courses, video conferencing, online presentations organized via the web -technologies: 
- virtual interactive whiteboard (for example, Glogster, Dabbleboard, Wikiwall, Scribblar, Padlet)

- webinars, online seminars, video conferences (for example, OpenMeetings, BigBlueButton, Adobe Connect Pro Meeting, EDU Conference, TeamViewer, Twitter, BigBlueButton, Mirapolis Virtual Room);

- collective editing and discussion of scientific research online (for example, Web 3.0, Skype, Windows Live);

- creation of virtual scientific communities (Facebook, Twitter, Linkedln, MySpace; Second Life).

C.ICT tools for checking the materials of scientific work - future computer science teachers can use ICT tools to check spelling and compliance with the requirements of the scientific style of the text of scientific work, translation of the necessary information into any language:

- online translation of foreign scientific texts (for example, Promt, Google Translator);

- check the text for uniqueness (for example, Advego Plagiatus, Etxt Antiplagiat);

- services for checking texts in the Ukrainian language (for example, Online Corrector, LanguageTool, Advego, Poetica, Test-the-Text, Draft, HamingwayApp, Readability).

D. Tools for checking software code for plagiarism:

- code plagiarism detectors (for example, MOSS, JPlag, SIM, Sherlock (BOSS), PMD(CMD), CodeMatch);

E. ICT tools to support experimental research - support the conducting of experimental scientific activities (collection, aggregation, processing of data and information) of future teachers of computer science by means of ICT, search and processing of statistical information for scientific research; tools to support project work, future computer science teachers can use them to display a list of tasks for the project (course and diploma works, conferences, competitions, etc.), schedule of joint meetings of problem groups and consultations with the head of scientific work:

- means of supporting scientific activity (for example, Google Suite for Education, Open Science Framework, QuizForce, WordForce, GoogleDocs, Spreadsheets, Gliffy (diagrams), GoogleWave, SharePoint, SPSS; GitHub).

F. ICT tools for creating demonstration material - general-purpose tools that can be used to create both dynamic and static demo material, web integration and bricolage systems that allow you to format and mix different formats of information and data, and process web pages with any level of HTML:

- web integration and bricolage systems (for example, Del.icio.us, SkypeMe, PingMe services, Yahoo Pipes);

- tools for creating mental maps (for example, Freemind, Coggle, Mindomo, MindMeister, XMind, Програма WiseMapping);

- means of creating dynamic and static demonstration material (for example, Prezi. com, ZohoShow, SlideShare, Vcasmo, Camtasia, Snagit, Office Sway, EdPuzzle, Googleslides; Canva, Piktochart, Snagit, Spark for Education, Easel.ly, Infogram).

The characteristics of ICT, which should be used in the organization of research work of future teachers of computer science, namely: the individualization of scientific work; the search engine optimization; the creation of the own electronic course by the scientific adviser; rapid distribution of the necessary material; the independent evaluation of scientific work of future computer science teachers; the variety of means of communication of subjects of research work; the convenient means for cooperation, etc. 


\section{Conclusions}

The introduction of information and communication technologies in the research work of higher education institutions of Ukraine contributes to increasing level of their competitiveness in the international market of educational services. Participation in the creation of a motivational and information environment for research work of future teachers of computer science forms not only professional qualities, but also immerses the student in the subject area of research. Thus, higher education students form and increase the level of their own competence in the use of ICT for the organization of research work. Prospects for the study are the search for ways to increase students' interest in research and identify the theoretical and methodological foundations of the integration of ICT in research activities of students HEI. Scientific research should be continued in such areas as training of computer science teachers and teachers of computer science disciplines with the use of ICT in the organization of research, as well as improving curricula and work programs of the discipline "Information and communication technologies in research" in training masters.

\section{References}

Kharkivska, A.A. (2012). Pidvyshchennia yakosti vyshchoi pedahohichnoi osvity cherez vykorystannia novitnikh informatsiinykh tekhnolohii [Improving the quality of higher pedagogical education through the use of the latest information technologies]. [in Ukrainian]

Law of Ukraine "On Higher Education" (2018) [Electronic resource]. Retrieved from http://zakon.rada.gov.ua/laws/show/1556-18. [in Ukrainian]

Minhalova, Yu.I. (2018). Informatsiino komunikatsiini tekhnolohii yak odyn iz zasobiv realizatsii naukovo doslidnoi diialnosti studentiv fizyko matematychnykh fakultetiv [Information and communication technologies as one of the means of realization of research activity of students of physics and mathematics faculties]. [in Ukrainian]

Minhalova, Yu.I. (2018). Orhanizatsiia studentskoi naukovo doslidnoi diialnosti na zaniattiakh iz dystsypliny "Osnovy naukovykh doslidzhen" [Organization of student research activities in classes on the subject "Fundamentals of Scientific Research"]. Zaporozhye: CPU. [in Ukrainian]

Minhalova, Yu.I. (2018). Pryntsypy vykorystannia hnuchkoho upravlinnia proektamy Scrum v naukovo doslidnii roboti studentiv [Principles of using flexible project management Scrum in research work of students]. Odessa: PU «Black Sea Research Institute of Economics and Innovation». [in Ukrainian]

Minhalova, Yu.I. (2019). Vykorystannia servisi Google dlia pidtrymky ta suprovodu studentskoi naukovoi diialnosti [Using Google service to support and support student research]. Kherson: Kherson State University. [in Ukrainian]

Vinnyk, M.O., Osypova, N.V., Tarasich, Yu.H., Savenko, A.P. (2014) Formuvannia doslidnytskykh kompetentnostei studentiv spetsialnosti "Prohramna inzheneriia" na prykladi vykladannia kursu "Hrupova dynamika ta komunikatsii" [Formation of research competencies of students majoring in "Software Engineering" on the example of teaching the course "Group Dynamics and Communication"]. [in Ukrainian] 